\title{
Inducing Constructivism and Post-Method in the Paradigm of Paragogy: A Proposed Learning Framework for Literacy Practice in EFL Context
}

\begin{abstract}
Riandi Riandi ${ }^{*}$
${ }^{1}$ MTs Negeri 6 Gunungkidul, Daerah Istimewa Yogyakarta, Indonesia

*Corresponding author. Email: riandi.zaini@gmail.com

ABSTRACT

This study aims to propose a learning framework that induces the concepts of paragogy overarching constructivism and post-method to ensure the creation of English language learning that involves the active participation of students and the synchronous development of EFL teaching and learning for literacy practice with the aim of national education, namely to prepare competent and reliable graduates in facing global competition. This research was designed using qualitative-interpretative methods commonly used in the library study. The research data were taken through a library study as the form of primary data. The conclusion of this study is in the form of recommendation of an English learning framework with inducement of the concepts of constructivism and post-method in the paradigm of paragogy suitable to be used in the development of English teaching and learning to improve student competency achievements.
\end{abstract}

Keywords: Constructivism, Literacy, Post-method, Paragogy, Framework.

\section{INTRODUCTION}

In the context of education, this means that the role of learning English in real life in the future is to prepare Indonesian citizens to be able to participate in the flow of information, goods, and service exchanges with foreign countries [1-3]. With the widespread use of English and the fact that English users are not only native speakers, even the majority of English users are not native speakers, students must be able to engage in interaction and communication with non-native speakers [4-7]. Therefore, interaction and communication where English is functioned as a lingua franca requires active involvement and ability of students in meaning-making [8-10].

As an impact, there is a shift in the purpose of learning English which was originally product-oriented, namely producing graduates or students who are able to speak English well and, in accordance with standard linguistic rules, become the goal of learning English that is oriented to the ability in the actual process of real communication, which involves students in reality and activates a real learning process [11-14]. The big question is how learning a language through the use of language can be realized in the context of the classroom, or more specifically how it is possible for foreign language learners to be able to activate the reality and linguistic resources in learning a language [15-18].

In fact, most English learning in Indonesia still follows predictable and pre-planned patterns by using lesson plans that follow the teacher exposure cycle learner response - follow up activities [19-22]. This triggers many shortcomings related to the unplanned spontaneous use of language. Some examples are the use of off-topic language, students' verbal reactions, teacher responses in the form of praise, reprimand, and punishment. All of which are not pre-planned in the lesson plan but these are examples of communication elements that students will use when in natural communication situations outside the classroom [23-26]. The need for learning that integrates interactions outside of learning tasks to bring students closer to communication patterns outside the classroom must be reached through an English learning framework [27, 28]. Therefore, EFL teaching and learning for literacy practice must be able to provide real-life interaction in addition to on-task interaction. When students are allowed to express themselves outside the conventional classroom, everyday language features such as humor or puns will appear sub-consciously which triggers students' quick reactions using linguistic and metalinguistic skills [29-31]. Therefore, there are needs 
of shifting the paradigm of the concept of learning as a transfer of knowledge into learning and learning experiences where students are guided to interpret what they learn and are given the opportunity to acquire softskills and life-skills so that the role of students as observers, listeners, passive recipients of information, has not shift is a condition where students know what to do and how to act in the certain context $[32,33]$.

Taking into account the above considerations, it is important that English language learning must apply a learning method that is oriented towards the future needs of students where they must learn English through their content so that in the end they can perform in the global competitive arena [34-36]. The development of the concepts of paragogy within the framework of learning English is constructivist in nature having complementary characteristics to achieve the proposed English learning objectives in the context of EFL teaching and learning. It is based on the idea that the traditional framework of English instruction is concerned with developing linguistic abilities only. As a result, students cannot meet the needs of future work competencies, mastery of English as an international communication tool.

The development of this framework also aims as an effort to strengthen the position of English language learning as the key to student success in the work environment. Policies need to be taken in order to develop a learning framework that supports the achievement of graduate competencies that can compete in the global market. The inducement of concepts of paragogy is expected to raise awareness in the English learning environment which will strengthen the position of students as subjects and no longer objects to activate the role of students in learning as subjects and learning English as a way to equip students with skills that adapts to the development of the era of computerized information where this is synchronous with the goal of national education, namely to prepare competent and reliable graduates in facing global competition.

\section{THEORIES WORTH CONSIDERING}

\subsection{Constructivist Language Instructions}

According to the constructivist approach, learning is the process of constructing learners' previous knowledge to gain the new knowledge [37]. Velásquez [37] affirms that the implication of constructivist approach is that the learner should be able to be actively engaged in the learning process and solve the problems during the learning. Learners are encouraged to be autonomous in the process of learning by doing.

On the other hand, teachers should provide learners with scaffolding to construct and adapt their understanding through processes of sensory and intellectual development through experience in the environment [38-40]. According to Vygotsky, learning occurs through interactions with the environment and the people in it $[41,42]$. Further, it is claimed that through the interaction, 'knowledge' is actively constructed by learners as they are trying to make sense of their experiences emphasizing the importance of context in learning and stress that the learning of knowledge could only be achieved by engaging in meaningful activities, and that language is an integral part of interaction, conveying messages occurs as the learners participating in the situations $[43,44]$.

Moreover, Wang [45] states that constructivism in language learning emphasizes in terms of how learners actively use information, resources, and help from others to build and improve their learning, encourage themselves to become autonomous, and get involved in the learning process. Therefore, constructivist classroom must provide a variety of challenging activities for the learners to make use of their possessed knowledge, discover new ideas, and increase their readiness to learn and construct their own knowledge meaningful from what is learned

\subsection{Models of English Language Instructions (outcome-based, value-based, content-based)}

In outcome-based education (OBE), the completion of the material is not the main goal of education, but rather on the learning outcomes achieved [46]. The claim that has been spread since its emergence is that OBE improves learning outcomes as the result of emphasizing the continuity of the learning process in an innovative, interactive, and effective manners allowing students to develop new skills that prepare them at a global level [47]. The educational process from designing curriculum, formulating learning objectives and achievements, designing learning methods and strategies, constructing assessment procedures, and developing the educational environment/ecosystem is influenced by the concept of outcome-based education (OBE) [46, 48].

One of the advantages of OBE to the application of teaching EFL is its appropriateness for the development of independent learning skills [49]. In addition, according to Khan and Bontha [50], outcome-based education enables schools to set academic standards aiming at students' learning outcomes as well as realizing the intended learning outcome. Therefore, EFL instruction in the context of OBE should be able to language content and language target demanded by the real-life condition.

On the other hand, Value-based education is a learning process that takes place with constant emphasis on the values of goodness and life contained in it [51-53]. It is claimed that value-based education liberates the education process to accommodate change and give true freedom that enables the teacher to create, innovate, and do experiment with notions of learning; a votary of 
teachers' rights to empower them to become the catalysts of change in achieving the goals of national education with sound value system and integrity of character by transforming the nature of education with the larger objectives of this s attempt $[54,55]$.

Furthermore, in EFL instructions, combining language and content becomes eminent in order to promote independent learners so they can continue the learning process even outside the classroom context. The emergence of content-based instruction (CBI) is considered as more a philosophy than a methodology. There is no single formula for this type of instruction but there are certain models of CBI which are used worldwide to achieve the goals of foreign language learning since it integrates language learning and content learning. Therefore, in a CBI course, the focus of learning is not on learning of a language in isolation, but rather learning of language through the study of subject matter $[56,57]$

A CBI curriculum is based on a main subject matter, uses authentic language and texts, and is developed based on learners' needs. This means that the curriculum is based on a certain subject matter and communicative competence is acquired in the context of learning about certain topics in that subject area. This falls under the top down approach to language learning where, unlike the bottom up approach, a learner first learns the overall meaning of a text and then attends to the language features [34]. Further, Dupuy [34] states the possibility of content-based instruction in making the development of beginner to advanced EFL learners easy by encouraging students' interests in the pursuit of language study beyond the current mastery level through bridging the basic language ability and the content of advanced courses.

The implementation of content-based instruction, however, meets several problems [34]. The first problem is the workload of the EFL teacher, especially if he does not have ample background knowledge on the subject matter, or the teacher of subject matters if he is not equipped with necessary skills and knowledge in English. Even though the teacher is well prepared to teach using the model, there is a particular concern on students' development of accuracy in the target language since the focus of the instruction is on the content. According to Messerklinger [58], the problem could be solved through providing much opportunity for the students to perform the target language in meaningful situations along with constant feedback. Conducting error recognition lessons is also beneficial in increasing grammatical accuracy. Another problem is that not all language could naturally appear in the content-based instruction. For example, all verb tenses could not be inclusively taught during the content lessons. The solution to the problem is to introduce specific context to introduce particular language, if not holding lessons to discuss the language not occurred in natural lessons.

In regards to advantages and drawback of CBI, there are several steps that can be accomplished to achieve the benefits of CBI [34]. They are selecting the most appropriate variation of CBI to the students' needs, adjusting the model of CBI, course content, and activities to the students' learning needs, and determining the learning guideline so that the teacher could arrange the strategies to make the content instruction more comprehensible for the students in which they are English foreign language learners.

To wrap things up, content-based language instruction is one of effective ways of EFL learning is facilitated by the content materials on the purposes of helping students to develop language skills in addition to motivating them to find interests and alternative ways of learning language. The goals of content-based instruction are achieved in certain conditions like students' interests and motivation, availability and affordability of authentic materials, supporting library, and highly proficient instructors so that they can provide purposeful activities employing the target language avoiding excessive language-focused learning to maintain conducive content learning with low-anxiety.

\subsection{Post-method Language Instruction}

The term pedagogy was chosen by Kumaravadivelu in order to overarch the issues of teaching and learning strategies, materials of instructions, curriculum goals, assessment and evaluation in language teaching and learning as well as the issues of historical, political and sociocultural conditions that influences the development of English language teaching and learning. Kumaravadivelu [59] mentions three parameter of postmethod pedagogy. They are particularity, practicality, and possibility. The particularity parameter implies the importance of language pedagogy which must be sensitive to certain groups of teachers who teach certain groups of learners who have a certain set of goals in certain learning contexts that are embedded in a certain sociocultural environment. The practicality parameters refer to the relationship between theory and practice with teaching practice in the classroom, the local educational, institutional, and social context must be considered properly. The last parameter is possibility closely related to power and domination, and is implemented to create and maintain social equality. The parameter of possibility is to recognize the position of learners and teachers, i.e. their class, race, gender and ethnicity, and for sensitivity to their impact on education. The idea of the possibility parameter is supported by Benesch [61] in her analysis on power relation in the academic setting. She claims that students should be aware of power relation in academic setting in which they would gain information on how decision related to their education are made so that they 
have the opportunity to challenge the limits of students as the object of learning and shift their role as the subject of learning contributing to the improvement of their own academic life.

The indicator of post-method pedagogy is the autonomy of teachers. Chen [62] affirms that postmethod pedagogy recognizes the existence of teachers' prior and current knowledge, and their potential to plan, implement and evaluate learning and act independently, taking into account the ability of teachers to know how to develop a reflective approach to their own teaching, how to analyze and evaluate their own teaching actions, how to initiate changes in the classroom, and how to monitor the effects of those changes. These skills lead a teacher to build his own practical theory [62].

Overall, post-method pedagogy is a new perspective in English language teaching and learning encouraging the learning opportunity for the students by creating less gaps between teachers' intention and students' interpretation. Teachers are to provide more freedom in learning, learning encouragement, empathetic communication, and broader options of teaching and learning. The parameters particularity, practicality, and possibility indicate the need for learning English as a foreign language as the means for students to get a learning atmosphere that is in accordance with their respective characters based on the theory of language teaching and learning that has been tested in real terms through practice in the field. In addition, the position of teachers and students in the context of learning is equal as subjects where teachers teach and deliver learning materials while students actively learn and develop themselves. Teachers are also encouraged to be autonomous in their daily tasks inferring professional independence of teachers in schools, especially the degree to which they can make autonomous decisions about what they teach to students and how they teach it. Thus, teachers should be able to understand how practice fits theory, connect theory and practice to generate grounded theories of practice and develop practical theories.

\subsection{Paragogy in Language Learning}

Corneli and Danoff [63] define paragogy as the peerto-peer learning and teaching. The principles of paragogy were derived from the Knowles' principles of andragogy on the specific context of peer-based learning. Paragogy focuses on the learning through peer supportive contexts in order to attain the self-directed learning. Peer-tutoring systems are enhanced to enable the learner to play roles in the learning process and set their learning goal. Furthermore, Corneli and Danoff [63] propose the principles of paragogy that are extracted from Knowles' five principles of the peer-based learning context. They are context as a decentered center, meta-learning as a font of knowledge, peers are equal, but different, learning is distributed and nonlinear, and realizing the dream, then wake up.

Based on the above discussion, below is the underlying theories of the proposed EFL framework.

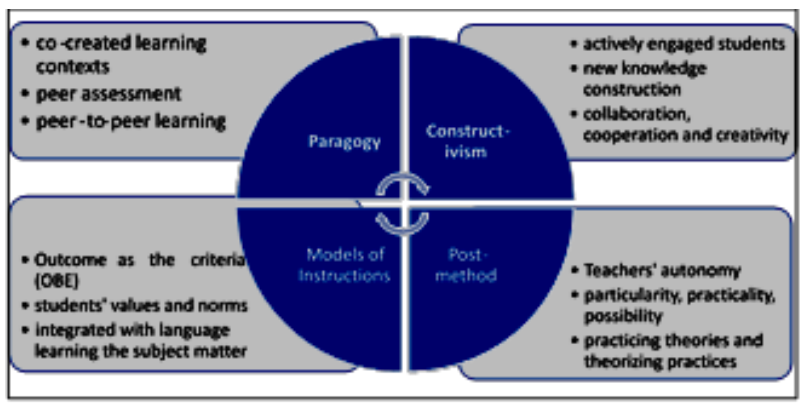

Figure 1 The Underlying Theories.

\section{METHODS}

The qualitative-interpretative methods commonly used in the library study were employed to develop the proposed EFL learning framework. The data were collected from theories related to constructivist language instructions, models of English language instructions, post-method era of language instruction, and the concepts of paragogy in language instruction. Then, content analysis was conducted to synthesize the concepts of paragogy overarching constructivism and post-method to be formulated into the proposed model. Finally, the model was analyzed and corroborated with the context of EFL learning to postulate the principles of the proposed framework.

\section{RESULTS AND DISCUSSION}

To ensure the development of an English learning framework adjusting to the demands of future work competencies (necessities), the need for mastery of English as an international communication tool (wants), as well as the scientific development of language teaching, an appropriate instructional framework inducing constructivism and post-method in the paradigm of paragogy is proposed here. It is expected that there will be an increase in the quality and mastery of graduate competencies that can fill the gap between the current competencies possessed by students and the needs and demands of English language competence in the world of work (lacks). At the same time, policies need to be taken in order to develop a learning framework that supports the achievement of graduate competencies that can compete in the globalized market. 


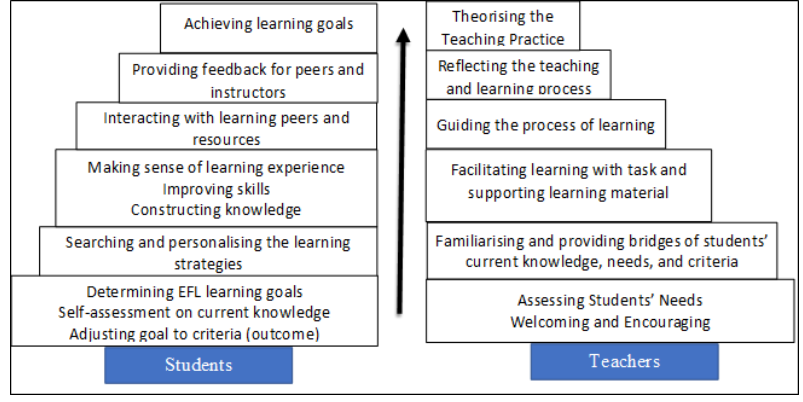

Figure 2 The Propased Framework.

\subsection{Phases in the Proposed Framework}

The framework has been developed by integrating constructivism and post-method in the paradigm of paragogy. The framework has six steps. Each is described as follow.

1. Teachers welcome and give encouragement to the students in taking the EFL as the general subject so that the needs assessment conducted could be able to assess students' actual needs in order to determine their EFL learning goals, self-assess their current knowledge, as well as adjusting goals to criteria (outcome).

2. Having the data on students' needs, teachers are to familiarize and provide bridges of students' current knowledge, needs, and criteria so that the students will be able to search and determine the learning strategies will be taken to attain their learning goals.

3. In order to facilitate students' learning, teachers should provide tasks and supporting learning materials allowing students to make sense of learning experience, improving skills, and constructing knowledge. It has been determined in the Government Law Number 51 year 2021 on the standards of national education that "challenging learning atmosphere" should be designed in order to encourage students to improve their competence continuously through tasks and activities with the appropriate difficulty level.

4. In the EFL teaching and learning for literacy practice process inducing constructivism and post-method in the paradigm of paragogy, teachers play their role as the facilitator and guide of the EFL teaching and learning process enabling students to be actively engaged in the process as the learning subject through interacting with learning peers and resources.

5. Conducing reflection on the process or EFL teaching and learning needs to be done by the teachers in order to gain information of benefits and problem faced during the instruction. Students also provide evaluation on the instruction through providing feedback for peers and instructors

\subsection{The Principles of the Proposed EFL Learning Framework}

As the goal of the framework is for students to be able to achieve the goals and for teachers to be able to theorizing their practice following the process of practicing the theories, there are principles of inducing constructivism and post-method in the paradigm of paragogy. They are:

1. EFL teaching and learning should be designed and carried out using the principles of practicality, particularity, and possibility.

2. EFL teaching and learning should provide students with much opportunity to perform the target language in meaningful situations along with constant feedback.

3. EFL teaching and learning environment is co-created through peer-learning, processes of action, reflection and construction by means of collaboration, cooperation and creativity.

4. Students' interests and motivation, availability and affordability of authentic materials, supporting library, and highly proficient instructors are needed to provide purposeful activities employing the target language as well as avoiding excessive languagefocused learning.

5. The essential indicators of the successful EFL teaching and learning are students achieving the learning goals and teachers theorizing their teaching practice

\section{CONCLUSION}

The discussion in the section above leads to the following conclusions. English as a universal language is used in various international communications online and offline so that mastery of English language competencies will enable students to connect with millions of people around the world. This requires mastery of competencies that will ensure successful intercultural communication. This implies that the achievement of mastery of English supports the achievement of mastery of global communication competencies and character formation in accordance with the curriculum mandate will be achieved through the proposed framework. In addition, there is a guarantee that the English language learning system, with its constructivism and paragogy content, becomes a means of achieving the goals of national education, namely further personal development and then professional development to achieve an adequate level of national and global citizenship.

\section{AUTHOR CONTRIBUTIONS}

All author conceived and designed this study. All author contributed to the process of revising the manuscript, and at the end all author has approved the final version of this manuscript. 


\section{ACKNOWLEDGMENTS}

First and foremost, I would like to express my greatest gratitude to The Almighty Allah SWT for the wondrous blessings throughout my life so that I can complete this paper. Due to the fact that this study is related to ICMR (International Conference of Madrasah Reform) 2021, I would also like to express my special gratitude to the Ministry of Religion, particularly those who are involved in Component 2 of Madrasah Reform.

\section{REFERENCES}

[1] A. Harahap, Preparing students for 'a real life' by implementing deeper learning method, Classroom Action Research Journal, 8(2) (2015) 282-308.

[2] F. Idris, Z. Hassan, A. Ya'acob, S. K. Gill, N.A.M. Awal, The role of education in shaping youth's national identity, Procedia-Social and Behavioral Sciences, 59 (2012) 443-450.

[3] R.S. Malik, Educational challenges in 21st century and sustainable development, Journal of Sustainable Development Education and Research, 2(1) (2018) 9-20.

[4] H.A. Alismail, P. McGuire, 21st century standards and curriculum: Current research and practice, Journal of Education and Practice, 6(6) (2015) 150154.

[5] L. M. Cakrawati, Students' perceptions on the use of online learning platforms in efl classroom, ELT Tech: Journal of English Language Teaching and Technology, 1(1) (2017) 22-30.

[6] K. Cassidy, Y. Franco, E. Meo, Preparation for Adulthood: A Teacher Inquiry Study for Facilitating Life Skills in Secondary Education in the United States, Journal of Educational Issues, 4(1) (2018) 33-46.

[7] F.M. Reimers, Transforming education to prepare students to invent the future, PSU Research Review, 2020 .

[8] W. Baker, The cultures of English as a lingua franca, Tesol Quarterly, 43(4) (2009) 567-592.

[9] S. Canagarajah, Lingua franca English, multilingual communities, and language acquisition, The modern language journal, 91 (2007) 923-939.

[10] A. Cogo, Strategic use and perceptions of English as a lingua franca, Poznań Studies in Contemporary Linguistics, 46(3) (2010) 295-312.

[11] C. Alptekin, towards intercultural communicative competence in ELT, ELT journal, 56(1) (2002) 5764.
[12] A. Cunningsworth, B. Tomlinson, Evaluating and selecting EFL teaching materials, Heinemann Educational, 1984.

[13] K. Shumin, Factors to consider: Developing adult EFL students' speaking abilities, Methodology in language teaching: An asnthology of current practice, 12 (2002). 204-211.

[14] W. Tian, A. French, Exploring Thai EFL learners' learning outcomes from a real-world interview task: A sociocultural perspective, Electronic Journal of Foreign Language Teaching, 16(2) (2019).

[15] É. Illés, Learner autonomy revisited, ELT journal, 66(4) (2012) 505-513.

[16] É. Illés and S. Akcan, Bringing real-life language use into EFL classrooms, Elt Journal, 71(1) (2017) 3-12.

[17] S. Madya, "Curriculum innovations in Indonesia and the strategies to implement them," ELT curriculum innovation and implementation in Asia, pp. $1-38,2008$.

[18] H. Maisyarah, S. Madya, The Needs of Intercultural Reading Materials for Accounting Students in Higher Education, 3rd International Conference on Current Issues in Education, Atlantis Press, 2019, pp. 230-235.

[19] M. A. Arifin, Designing a lesson plan for Indonesian adult students by using TBLT (Task based language teaching), English, Teaching, Learning, and Research Journal, 4(1) (2018) 43-66.

[20] M. Fatoni, An analysis of directed dialogue journal to improve writing skill on news items texts for indonesian EFL University Students, Jurnal Pendidikan Edutama, 6(1) (2019) 1-10.

[21] A. Rido, Why they act the way they do?: Pedagogical practices of experienced vocational English language teachers in Indonesia, International Journal of Language Education, 4(2) (2020) 24-37.

[22] W.K. Too, E. J. Saimima, Teacher belief and practice in a school-based English language classroom in eastern Indonesia, Journal of Nusantara Studies (JONUS), 4(1) (2019) 211-231.

[23] E. W. Chizhik, A. W. Chizhik, Using activity theory to examine how teachers' lesson plans meet students' learning needs, The Teacher Educator, 53(1) (2018) 67-85.

[24] K. Habibi, Effectiveness of lesson planning in teaching EFL (English as A Foreign Language), International Journal of Science and Research (IJSR), 9(6) (2020) 999-1003. 
[25] L. Rusznyak, E. Walton, Lesson planning guidelines for student teachers: A scaffold for the development of pedagogical content knowledge, Education as change, 15(2) (2011) 271-285.

[26] J.A. Zahorik, The effect of planning on teaching, The Elementary School Journal, 71(3) (1970) 143151.

[27] E. Córdoba Zúñiga, Implementing task-based language teaching to integrate language skills in an EFL program at a Colombian university, Profile Issues in Teachers Professional Development, 18(2) (2016) 13-27.

[28] I. Ozverir, J. Herrington, Authentic activities in language learning: Bringing real world relevance to classroom activities, EdMedia+ Innovate Learning, Association for the Advancement of Computing in Education, 2011, pp. 1423-1428.

[29] A. Adnan, L. Marlina, EFL Students' Learning Style in English as General Course at Universitas Negeri Padang, 2017.

[30] A. Norizkyka, Y. Hermaniar, Concealed character values on lecturers'verbal feedback in english teaching, UAD TEFL International Conference, 1 (2017) 7-14.

[31] Y.A. Rani, D. F. Kher, The Students of International Physics Class at UNP: How Do They Acquire English?, 7th International Conference on English Language and Teaching, Atlantis Press, 2020, pp. 195-199.

[32] Y. Matsuyama, M. Nakaya, H. Okazaki, A. J. Lebowitz, J. Leppink, C. Van Der Vleuten, Does changing from a teacher-centered to a learnercentered context promote self-regulated learning: a qualitative study in a Japanese undergraduate setting, BMC medical education,19(1) (2019) 1-12.

[33] F. Waninge, Z. Dörnyei, K. De Bot, Motivational dynamics in language learning: Change, stability, and context, The Modern Language Journal, 98(3) (2014) 704-723.

[34] B. C. Dupuy, Content-based instruction: Can it help ease the transition from beginning to advanced foreign language classes?, Foreign language annals, 33(2) (2000) 205-223.

[35] S. Hamidova, H. Ganiyeva, Development of professional competence in learning foreign languages for students of non-language higher education institutions, International Journal of Research and Development, 5(1) (2020).

[36] A. Kotova, V. Serdyuk, I. Avdieienko, O. Lenska, O. Ivaniga, Integration of content and language integrated learning elements in the education of nonlinguistic specialty students by means of information technologies, society integration education Proceedings of the International Scientific Conference, 1 (2021) 316-326.

[37] T.B. Velásquez, Hybrid Method An integrated pedagogical method for EFL teaching and learning, Zona próxima: revista del Instituto de Estudios Superiores en Educación, 17(2012) 194-211.

[38] S.E. Fox, P. Levitt, C. A. Nelson III, How the timing and quality of early experiences influence the development of brain architecture, Child development, 81(1) (2010) 28-40.

[39] H.-M. Huang, U. Rauch, S.-S. Liaw, Investigating learners' attitudes toward virtual reality learning environments: Based on a constructivist approach, Computers \& Education, 55(3) (2010) 1171-1182.

[40] E.M. Simatwa, Piagets theory of intellectual development and its implication for instructional management at pre-secondary school level, Educational research and reviews, 5(7) (2010) 366371.

[41] A. Firth, J. Wagner, Second/foreign language learning as a social accomplishment: Elaborations on a reconceptualized SLA, The modern language journal, 91 (2007) 800-819.

[42] A. Ribeiro, W. Jiang, Enhancing ELLS'second language acquisition with interactions, Kappa Delta Pi Record, 56(2) (2020) 77-81.

[43] J. Collentine and B.F. Freed, Learning context and its effects on second language acquisition: Introduction, Studies in second language acquisition, 26(2) (2004) 153-171.

[44] A. Scarino and A. Liddicoat, Teaching and learning languages: A guide, Curriculum Corporation Melbourne, 2009.

[45] P. Wang, Constructivism and learner autonomy in foreign language teaching and learning: To what extent does theory inform practice, Theory and Practice in Language Studies, 1(3) (2011) 273-277.

[46] W.G. Spady, Outcome-Based Education: Critical Issues and Answers, ERIC, 1994.

[47] M. Tam, Outcomes-based approach to quality assessment and curriculum improvement in higher education, Quality assurance in education, 2014.

[48] G. N. A. Sukerti, N. N. Yuliantini, K. Y. Susana, Developing an outcome-based esp course with blended-learning method for computer students in higher vocational education, ISoLEC Proceedings, 4(1) (2020) 14-19. 
[49] K.F. Wijaya, The impacts of outcome-based education for efl learners'learning autonomy in the introduction to education class, ELTIN JOURNAL, Journal of English Language Teaching in Indonesia, 8(2) (2020) 75-90.

[50] K. Khan, U.R. Bontha, Outcomes-Based Assessment in an English Language Program, Revisiting EFL Assessment: Springer, (2017) 85104.

[51] J. Blewitt, J.M. Blewitt, J. Ryan, Business forums pave the way to ethical decision making: The mediating role of self-efficacy and awareness of a value-based educational institution, Journal of Business Ethics, 149(1) (2018) 235-244.

[52] R.B. Iyer, Value-based education: Professional development vital towards effective integration, IOSR Journal of research and method in education, 1(1) (2013).

[53] M. Mumpuniarti, F. Fathurrohman, S. Sukinah, Value-Based Education Model to Build Students of Inclusive Elementary School's Character, Dewantara, 2(1) (2014).

[54] S. Porntaweekul, S. Raksasataya, T. Nethanomsak, Developing reflective thinking instructional model for enhancing students desirable learning outcomes, Educational Research and Reviews, 11(6) (2016) 238-251.

[55] N. Sari, The importance of teaching moral values to the students, Journal of English and Education, 1(1) (2013) 154-162.

[56] C. Bazerman, N. Keranen, F. Encinas, Facilitated immersion at a distance in second language scientific writing, University writing: Selves and texts in academic societies, (2012) 235-248.

[57] K. R. Harris, S. Graham, Constructivism: Principles, paradigms, and integration, The journal of special education, 28(3) (1994) 233-247.

[58] J. Messerklinger, Language immersion and contentbased language learning, what's the difference? A survey of different language programs, 2007 URL: http:/www. messerklinger. blogspot.

[59] B. Kumaravadivelu, Toward a postmethod pedagogy, TESOL quarterly, 35(4) (2001) 537-560.

[60] B. Kumaravadivelu, A postmethod perspective on English language teaching, World Englishes, 22(4) (2003) 539-550.

[61] S. Benesch, Rights Analysis: Studying Power Relations in an Academic Setting, English for specific purposes, 18(4) (1999) 313-327.
[62] M. Chen, Postmethod Pedagogy and Its Influence on EFL Teaching Strategies, English Language Teaching, 7(5) (2014) 17-25.

[63] J. Corneli, C. J. Danoff, Paragogy, In Proceedings of the 6th Open Knowledge Conference, CEUR Workshop Proceedings, Berlin, Germany, 2011. 